\title{
Efektivitas Komunikasi Pemerintahan dalam Pelayananan Publik pada Kantor Pertanahan Nasional Kota Kendari
}

\author{
Miftahul Jannah ${ }^{1}$; La Tarifu ${ }^{2}$; Saidin ${ }^{3}$ \\ ${ }^{123}$ Universitas Halu Oleo, miftahuljanah277@gmail.com
}

\begin{abstract}
Abstrak
Penelitian ini bertujuan untuk mengetahui dan mendeskripsikan efektivitas komunikasi pemerintahan dalam pelayanan publik di Kantor Pertanahan Nasional Kota Kendari. Untuk mengetahui tujuan tersebut digunakan metode penelitian kualitatif untuk menggali informasi-informasi dari informan yang bersifat terbuka dan bebas dengan 5 orang informan. Penelitian ini dilakukan pada Kantor Pertanahan Nasional Kota Kendari dengan jenis data berupa data primer dan data sekunder. Instrumen penelitian sendiri dilakukan dengan dokumentasi, wawancara, dan observasi. Hasil penelitian ini menunjukan bahwa efektivitas komunikasi pemerintahan dalam pelayananan publik pada Kantor Pertanahan Nasional Kota Kendari, dapat diperoleh kesimpulan sebagai berikut bahwa keberhasilan komunikasi merupakan kunci keberhasilan dalam mencapai tujuan Kantor Pertanahan Nasional seperti komunikasi internal dan komunikasi ekternal dan pelayanan yang dilakukan Kantor Pertanahan Nasional kota Kendari sudah cukup efektif, dilihat dari 3 indikator yaitu sumber komunikator, media dan efek komunikasi.
\end{abstract}

Kata kunci : Efektivitas, Komunikasi, Pemerintahan. Pelayanan, Pertanahan.

\begin{abstract}
This study aims to determine and describe the effectiveness of government communication in public services at National Land Office of Kendari City. To find out these objectives, a qualitative research method was used to extract information from informants that were open and free with 5 informants. This research was conducted at the Kendari City National Land Office with the type of data in the form of primary data and secondary data. The research instrument itself is carried out with documentation, interviews, and observations. The results of this study indicate that the effectiveness of government communication in public service at the National Land Office of Kendari City, the following conclusions can be obtained that the success of communication is the key to success in achieving the goals of the National Land Office such as internal communication and external communication and services provided by the National Land Office of the city of Kendari it is quite effective, seen from 3 indicators namely source communicator, media and communication effects.
\end{abstract}

Keywords : Communication, Governance, Effectiveness, Service, Land 


\section{Pendahuluan}

Menciptakan sebuah organisasi yang baik dan mencapai tujuan secara maksimal diperlukan metode komunikasi yang baik pula. Mencapai tujuan secara maksimal diperlukan metode komunikasi yang baik dan juga untuk mencapai tujuan secara maksimal diperlukan metode komunikasi yang baik agar tercipta komunikasi yang efektif dan efisien. (Aeni : 2001)

Penting dalam pelaksanaan pelayanan publik di Kantor Pertanahan Nasional Kota Kendari adalah kemampuan publik seseorang petugas layanan dalam berinteraksi dan berkomunikasi dengan orang lain. Komunikasi adalah hal yang paling lumrah dilakukan dalam orang memberikan layanan. Nilai baik tidaknya sebuah layanan sering kali diliat dari berbagaimana cara petugas pemberi layanan dalam berkomunikasi dengan masyarakat. Untuk keterampilan dengan komunikasi ini harus dimiliki dan dikuasai dengan baik oleh setiap petugas pemberi layanan. Pelayanan publik adalah pemberian jasa yang diberikan oleh suatu organisasi (perusahan, swasta, pemerintah) kepada publiknya dengan atau tanpa pembayaran guna memenuhi kebutuhan dan kepentingan masyarakat.

Ada pula masyarakat Kendari yang ingin melakukan pengurusan pelayanan administrasi pertanahan yang kesulitan karena kurangnya informasi dan sosialisasi mengenai tatacara pengurusan, baik itu pengurusan sertifikat atau halhal lain yang berkaitan dengan pelayanan administrasi pertanahan. Pada kondisi seperti ini, kantor-kantor pelayanan publik diharapkan mampu memberikan solusi agar masyarakat tidak kebingungan, misalnya dengan memasang papan informasi bicara sehingga masyarakat itu sendiri mampu menelaah proses dan alur pelayanan adminstrasi pertanahan pada saat akan melakukan pengurusan.

Belum efektifnya pelayanan publik yang terjadi selama ini karena tidak adanya paradigma yang jelas dalam penyelengaraan pelayanan publik. Kinerja pelayanan yang diberikan oleh birokrasi yang ada di Indonesia masih cukup kuat watak mengabdi pada kekuasaan dibandingkan kepada publik sehingga wajah birokrasi Indonesia kesan otoriternya cukup kuat. Dengan situasi birokrasi demikian, tentu dalam pelaksanaan pelayanan publik yang diberikan oleh birokrasi akan terpusat pada pola tertentu. Di mana pola tersebut masih jauh dari kesan 
demokratis dan berkualitas dan yang nampak adalah kesan diskriminatif. Pelayanan di Kantor Pertanahan belum sepenuhnya berjalan sesuai dengan ketentuan yang berlaku. Dalam hal ini terjadi pada Kantor Pertanahan Nasional Kota Kendari yang permohon atas hak tanah atau pelanggan terkadang mengeluhkan atas Pelayanan Kantor Pertanahan yang tergolong lama dan tidak tepat waktu. Berdasarkan hal tersebut maka penelitian ini bertujuan untuk mengetahui efektivitas komunikasi pemerintahan dalam pelayanan publik pada Kantor Pertanahan Nasional Kota Kendari.

\section{Metode}

Penelitian ini bersifat deskriptif dengan subjek penelitian dalam penelitian ialah pegawai yang bekerja di Kantor Pertanahan Nasional Kota Kendari. Adapun Informan penelitian adalah pegawai Kantor Pertanahan Nasional yang bekerja di bagian Pelayanan Administrasi/Publik sebanyak 5 orang terdiri atas Kepala Badan Pertanahan Nasional Kota Kendari, Kepala Bidang Pelayanan Publik, Kasi Pelayanan Administrasi, staf pelayanan di Kantor Pertanahan dan masyarakat yang datang melaksanakan pengurusan di Kantor Pertanahan Nasional Kota Kendari. Teknik pengumpulan data yang digunakan adalah observasi, wawancara dan dokumentasi. Sedangkan teknik analisis data menggunakan analisis deskriptif kualitatif.

\section{Hasil dan Pembahasan}

\section{Pelayanan Administrasi Kantor Pertanahan Nasional Kota Kendari}

\section{a. Pendaftaran Tanah}

Pasal 1 Angka 1 PP Pendaftaran Tanah menyatakan bahwa "pendaftaran tanah adalah rangkaian kegiatan yang dilakukan oleh pemerintah secara terus menerus, berkesinambungan dan teratur, meliputi pengumpulan, pengolahan, pembukuan, dan penyajian serta pemeliharaan data fisik dan data yuridis, dalam bentuk peta dan daftar, mengenai bidang-bidang tanah dan satuan-satuan rumah susun, termaksud pemberian surat tanda bukti haknya bagi bidang-bidang tanah 
yang sudah ada haknya dan hak milik atas satuan rumah susun serta hak-hak tertentu yang membebaninya.

A.P. Parlindungan, sebagaimana dikutip oleh Urip Santoso, pendaftaran tanah berasal dari kata cadastre, yang dalam bahasa belanda disebut kadaster, cadastre adalah suatu istilah teknis untuk suatu record (rekaman) yang menunjukan kepada luas, nilai dan kepemilikan (atau lain-lain atas hak) terhadap suatu bidang tanah.

Kantor Pertanahan Nasional Kota Kendari memiliki standar pelayanan dan pengaturan pertanahan, badan pertanahan nasional Kota Kendari berdasarkan peraturan KBPN RI nomor 1 tahun 2010 yang menyelesaikan masalah pelayanan pendaftaran tanah, pelayanan pencatata, pelayanan pengukuran bidang tanah, pengelolaan pengaduan dan informasi pertanahan

Adapun proses pendaftaran tanah di Kantor Badan Pertanahan Nasional Kota Kendari, berdasarkan penjelasan KASUBSI Pendaftaran Hak Tanah Badan Pertanahan Nasional Kota Kendari bahwa untuk membuat pendaftaran tanah, masyarakat harus memenuhi beberapa persyaratan surat keterangan pendaftaran tanah adapun persyaratan yang harus di penuhi masyarakat yaitu formulir permohonan yang sudah diisi dan ditanda tanggani permohon atau kuasanya di atas materai cukup, surat kuasa apabila dikuasakan, fotokopi identitas pemohon $(\mathrm{KTP}, \mathrm{KK})$ dan kuasa apabila dikuasakan, yang telah dicocokkan dengan alisnya oleh petugas loket,bukti hubungan hukum antara subjek dan objek hak, dan waktu yang diperlukan empat hari kerja, serta keterangannya yang di perlukan adalah identitas diri, luas, tetak dan penggunaan tanah yang dimohon, biaya yang diperlukan lima puluh ribu rupiah persurat keterangan pendaftaran tanah. (Muhtar Idrus, 2019).

\section{b. Pembuatan Sertifikat Tanah}

Istilah "sertifikat" berasal dari bahasa inggris (certificate) yang berarti ijazah atau surat keterangan yang dibuat oleh pejabat tertentu dengan pemberian surat keterangan berarti pejabat yang bersangkutan telah memberikan status tentang keadaan seseorang dan Istilah "sertifikat tanah" dalam bahasa indonesia diartikan 
sebagai surat keterangan tanda bukti pemengag hak atas tanah dan berlaku sebagai alat pembuktian yang kuat, dengan pernebitan sertifikat tanah hak atas tanah bahwa telah menerangkan bahwa seseorang itu mempunyai hak atas suatu bidang tanah, ataupun tanah seseorang itu dalam kekuasaan tanggungan, seperti sertifkat hipotek atau kreditverband, berarti tanah itu terkait dengan hipotek atau kreditverband (Budi Harsono, 1998).

Sertifikat tanah dapat diliat dasarnya yaitu dalam undang-undang pokok agraria (UUPA) pasal 19 menyebutkan bahwa ayat (1) untuk menjaminkan kepstian hukum oleh pemerintah diadahkan pendaftaran tanah diseluruh wilaya republik indonesia menurut ketentuan-ketentuan yang diatur dengan peraturan pemerintah dan ayat (2) pendaftaran tersebut dalam ayat (1) pasal ini meliputi pengukuran, pemetaan dan pembukuan tanah, pendafta ran hak-hak atas tanah dan perahlian hakhak, pemberian surat-surat tanda bukti hak, yang berlaku sebagai alat pembuktian yang kuat.

Adapun proses pembuatan sertifikat di Badan Pertanahan Kota Kendari berdasarkan penjelasan dari Kepala Kantor Pertanahan Nasional Kota Kendari bahwa sebelum pembuatan sertifikat tanah harus mengajukan permohonan pembutan sertifikat terlebih dahulu dan beberapa dokumen yang diperlukan sebagai syarat pembuatan sertifikat tersebut ialah, fotokopi kartu tanda penduduk (KTP), fotokopi kartu keluarga (KK), fotokopi NPWP, membawa bukti perolehan tanah, fotokopi bukti pembayaran PPB tahun terakhir, peryataan tanah tidak sengketa,dan waktu yang diperoleh pembuatan sertifikat tanah tergantung dari luas tanah dan jenis peruntukan tanah tesebut 15 (lima belas) hari kerja untuk paling banyak 5 (lima) bidang tanah, lama penyelesaian untuk kegiatan lebih dari 5 (lima) bidang tanah menyesuaikan. Untuk tarif pembayaran pengurusan sertifikat tanah sebenarnya tergantung dari lokasi seperti (luas tanah/ 500) $\times \mathrm{Rp} .80 .000+\mathrm{Rp}$. 100.000, (luas tanah / 500) × Rp. 40.000 + Rp. 100.000." (Irwan Idrus, 2019).

Sebagaimana yang dimaksud pada pasal 29 ayat 1 adalah bukti hak yang bersangkutan beserta pemegang haknya dalam bidang tanahnya yang dijelaskan dalam surat ukur secara hukum sudah terdaftar menurut peraturan pemerintah, sementara sertifikat diterbitkan untuk kepentingan pemengang hak yang 
bersangkutan sesuai dengan data-data buku tanah dalam pasal 30 ayat (1) sertifikat hanya diserahkan kepada pemiliknya

Dalam pembuatan sertifikat tanah hanya boleh diserahkan kepada pihak yang namanya tercantum dalam buku tanah merupakan dokumen yang memuat data yuridis dan data fisik tanah yang sudah ada haknya, sedangkan sertifikat tanah merupakan surat tanda bukti hak atas tanah yang sudah dibukukan dalam buku tanah, dan pengurusan sertifikat tanah masyarakat harus melengkapi dokumen yang telah ada, setelah itu anda harus menunggu dikeluarkannya surat keputusan. Di bebankan BAE perolehan Hak Atas Tanah (BPHTB) sambi menunggu keluarnya sertifikat tanah yang di terbitkan, waktu penerbitanya kurang lebih 15 hari kerja lamanya paling banyak 5 bidang tanah yang selesai. Kadangkala, masyarakat perlu memastikan kepada petugas BPN kapan sertifikat tanah di ambil.

\section{c. Pembuatan Akta Tanah}

Istilah PPAT sudah dikenal sejak berlakunya peraturan pemerintah nomor 10 tahun 1961 tentang pendaftaran tanah, yang merupakan peraturan pelaksanaan undang-undang nomor 5 tahun 1960 tentang peraturan pokok-pokok agraria atau atau di lebih dikenal UUPA. Didalam peraturan tersebut untuk pertama kalinya PPAT disebut sebagai pejabat yang berfungsi membuat akta yang bermaksud memindahkan tanah, memberikan hak baru atau membebankan hak atas tanah.dalam buku hukum agraria indonesia yang tertulis boedi harsono, terbitan djambatan jakarta 2002 dikemukakan bahwa pengertian PPAT dapat diliat dalam pasal 1 peraturan pemerintah nomor 37 tahun 1998 tentang peraturan jabatan PPAT yaitu pejabat pembuatan akta tanah.

PPAT adalah pejabat umum diberi kewenangan untuk membuat akat-akta oteritik mengenai pembuatan hukum tertentu mengenai hak atas tanah atau hak milik atas satuan rumah susun. Akta yang dapat dibuat PPAT terdapat berbagai macam, yaitu Akta jual beli, Akta hibah, Akta tukar menukar, Akta pembagian hak bersama, Akta pemasukan ke dalam perusahaan, Akta pemberian Hak Tanggungan, Akta pemberian kuasa membebankan Hak Tanggungan, Akta pemberian Hak Guna Bangunan/ Hak Pakai atas tanah Hak Milik. 
Informasi dari KASUBSI Pemeliharaan Data hak Tanah dan Pembinaan PPAT bahwa dalam pembuatan akta tanah itu harus memenuhi beberapa syarat yang telah ditentukan, fotokopi indentitas (KTP, KK), sertifikat asli, akta jual beli tanah dan formulir yang sudah diisi dan waktu yang diperlukan 2-3 hari paling lama.(Sultra Wirawan, 2019). Ketika masyarakat memerlukan pelayanan untuk membuat akta peralihan hak harus terlebih dahulu melakukan pelunasan pembayaran pajak BPHTB. Pembuatan akta tanah sama halnya seperti mengurus sertifikat tanah hanya yang membedakannya adalah sertifikat tanah adalah salah satu contoh legalitas yang paling sering ditanyakan oleh masyarakat, sedangkan akta tanah adalah bukti bahwa hak yang bersangkutan beserta pemengang hak tanahnya yang diuraikan dalam surat ukur secara hukum.

\section{Efektivitas Komunikasi Pemerintahan dalam Pelayanan Publik di Kantor Pertanahan Nasional Kota Kendari}

Komunikasi adalah saluran untuk melakukan dan menerima pegaruh mekanisme perubahan, alat untuk mendorong mempertinggi motivasi dan juga perantara serta sarana di mana kemungkinan suatu organisasi mencapai tujuannya. Perilaku manusia adalah cermin yang paling sederhana, agar perilaku seseorang sesuai dengan tujuan organisasi, maka harus ada kesesuaian antara keinginan karyawan dengan keinginan perusahaan. Pimpinan perusahan dalam melakukan intruksi, bimbingan, penerangan, laporan, selalu mengadakan komunikasi terhadap karyawan berwujud pemberian perintah atau dan lainnya.

Komunikasi internal merupakan komunikasi yang terjadi dalam lingkungan kantor atau organisasi. Komunikasi ini bisa terjadi antara karyawan dengan karyawan, karyawan dengan atasan, dan atasan dengan atasan. Komunikasi in terjadi karena terdpat sebuah struktur dalam organisasi. Dalam Kantor Pertanahan Nasional Kota Kendari komunikasi internal Sangatlah diperlukan untuk menunjang keberhasilan pelayanan seperti dalam penetapan pengurusan pendaftaran tanah, akta tanah, dan sertifikat tanah, itu dilakukan melalui rapat, mengembangkan kualitas karyawan. 
Komunikasi eksternal adalah segenap kegiatan komunikasi yang diarahkan pada publik siluar organisasi pemerintah (masyarakat umum, target graup, partai politik, tokoh-tokoh masyarakat dan sebagainya), bukannya kalangan dalam organisasi pemerintah yang bersangkutan. Komunikasi eksternal merupakan komunikasi yang dilakukan di luar organisasi yaitu atasan atau aparat pemerintahan dengan masyarakat umum dalam suatu pelayanan administrasi baik informasi, seperti penyampaian informasi mengenai tanah dalam Kantor Pertanahan. Ada beberapa bentuk komunikasi eksternal dalam pemerintahan yaitu:

\section{a. Sumber/Komunikator}

Sumber / komunikator adalah pembuat atau pengirim informasi. Dalam komunikasi antar manusia, sumber bisa terdiri dari satu orang, tetapi bisa juga dalam kelompok misalnya partai, organisasi atau lembaga. Sumber biasa disebut juga komunikator atau dalam bahasa Inggrisnya disebut source, sender atau decoder.

Komunikator merupakan seseorang atau organisasi yang melakukan penyampaian pesan dan informasi untuk mewujudkan pesan komunikasinya. Menjadi sumber / komunikator dalam memberikan informasi tentang pelayanan publik dimasyarakat melalui Kantor Pertanahan Nasional Kota Kendari selaku KASUBSI penataan hak tanah dan pemberdayaan masyarakat. Hal ini dapat dilihat dari hasil wawancara KASUBSI Penataan Hak Tanah dan Pemberdayaan Masyarakat menyatakan bahwa "Sumber/ komunikatornya adalah Kantor Pertanahan Nasional Kota Kendari dan yang turun langsung dimasyarakat untuk menyampaikan informasi adalah KASUBSI Penataan Hak Tanah dan Pemberdayaan Masyarakat dan Staf pengawai lainnya yang berkerja di Kantor Pertanahan Nasional Kota Kendari” (Sukma, 2019).

Berdasarkan hasil wawancara dapat diketahui bahwa di Kantor Pertanahan Nasional Kota kendari hanya berupa menyampaikan informasi-informasi kepada masyarakat tentang pelayanan pendaftaran tanah, pembuatan sertifikat tanah dan pembuatan akta tanah. Mengingat hal tersebut sumber/ komunitor Pertanahan Kota Kendari sejalan dengan tugas pokok yang ada di Kantor Pertanahan Nasional Kota Kendari. Dan dari hasil observasi yang dilakukan penelitian bahwa sumber/ 
komunikator di Kantor Pertanahan Nasional Kota Kendari tidak sesuai dengan apa yang terjadi di lapangan, melihat kondisi tersebut banyak masyarakat yang datang mengeluh dalam pengurus administrasi.

Hal yang sama juga dikatakan oleh KASUBBAG TU yang menyatakan bahwa "Sumber/komunikator dilakukan oleh Kantor Pertanahan Nasional Kota Kendari untuk menyampaikan informasi kepada masyarakat yang dilakukan oleh staf-staf yang turun langsung di lapangan untuk menginformasikan kepada masyarakat tentang pengurusan pertanahan" (Andi Nur Aeni,2019). Berdasarkan hasil wawancara diketahui bahwa sumber/komunikator di Pertanahan Kota Kendari untuk meningkatkan pelayanan publik dimasyarakat khususnya di Kantor Pertanahan Nasional Kota Kendari sudah berjalan dengan prosedurnya dalam menyampaikan informasi kepada masyarakat.

Lebih lanjut berdasarkan wawancara dari masyarakat "menurut saya sumber/komunikator yang ada di Kantor Pertanahan Nasional Kota Kendari tidak sesuai dengan yang dinformasikan kepada masyarakat dalam melakukan pengurusan pelayanan administrasi karna secara langsung pengurusannya tidak sesuai prosedur yang ada di Kantor Pertanahan Nasional Kota Kendari” (Sandra, 2019). Berdasarkan wawancara bahwa masyarakat memang menerima informasi sesuai dengan prosedur yang ada tetapi banyak masyarakat yang datang mengurus di Kantor Pertanahan Nasional Kota Kendari masih kurang efektif dengan pelayanan administrasinya.

Maka dari hasil wawancara beberapa informan dapat disimpulkan bahwa Kantor Pertanahan Nasional Kota Kendari dalam melaksanakan aktivitas Pelayanan Pertanahan yang bertindak sebagai sumber/komunikator adalah staf pertanahan baik dikantor atau yang turun langsung dilapangan untuk menyampaikan informasiinformasi yang akurat untuk masyarakat tentang pengurusan pertanahan. Tetapi masyarakat masih banyak yang mengeluh tentang Pelayanan Administrasi Pertanahan karena yang diinformasikan tidak sesuai dengan Pelayanan yang di berikan di Kantor Pertanahan Nasional Kota Kendari. 


\section{b. Media/ alur}

Media adalah media online (daring) yang dimanfaatkan sebagai sarana pergaulan sosial secara online di internet. Di media sosial, para penggunanya dapat saling berkomunikasi, berinteraksi, berbagi, networking, dan berbagai kegiatan lainnya. Media sosial mengunakan teknologi berbasis website atau aplikasi yang dapat mengubah suatu komunikasi ke dalam bentuk dialog interaktif. Beberapa contoh media sosial yang banyak digunakan adalah YouTube, Facebook, Blog, Twitter, dan lain-lain.

Media Merupakan jalan yang dilalui oleh komunikator agar sampai pada masyarakat dan media komunikasi yang digunakan adalah melalui papan pengumuman yang diberikan atau disajikan yaitu informasi terkait tentang waktu pelaksanaan, waktu pengurusannya, informasi-informasi terkait tentang syarat Pelayanan Administrasi Pertanahan Kota Kendari. Hal ini dapat di lihat dari hasil wawancara dengan Kepala Kantor Pertanahan Nasional Kota Kendari bahwa "Bentuk penyampaian informasi pertanahan kepada masyarakat adalah sosialisasi langsung kepada masyarakat, prosedur-prosedur, pelayanan langsung atau sosialisasi diluar kantor (one day servis dilippo plaza kendari), sosialisasi melalui pamflet, pengumuman" (Irwan Idrus, 2019).

Berdasarkan hasil wawancara diketahui bahwa di Kantor Pertanahan Nasional Kota Kendari dalam menyampaikan informasi kepada masyarakat yang digunakan adalah media komunikasi berupa sosialisasi diluar kantor, internet, pamflet dan papan penggumuman.

Lebih lanjut wawancara dengan KASI Penataan Pertanahan menyatakan bahwa "media yang digunakan adalah media tulisan seperti email (kotkendari@bpn.yo.id), aplikasi SENTU TANAHKU, facebook (bpn kota kendari) dan komunikasi dilakukan secara langsung dan bertatap muka " (Jasip, 2019).

Berdasarkan wawancara bahwa di Kantor Pertanahan Nasional Kota Kendari menggunkan media komunikasi dapat dilihat data tentang pelayanan administrasi pertanahan bisa kita buka situsnya di "Sentu Tanahku", nanti akan muncul informasi-informasi mulai dari daftar perkembangan pengurusan berkas, informasi sertifikat tanah, informasi layanan syarat biaya dan jangka waktu 
penyelesaian serta simulasi biaya dan informasi pemetaaan batas tanah sesuai dengan sertifikat fisik. jadi terserah dari pengguna saja mau cari informasi yang ada.

Adapun pesan-pesan yang disampaikan kepada masyarakat tentang Informasi Pertanahan ialah menyampaikan pesan-pesan kepada masyarakat bahwa sertifikat tanah yang dimiliki harus didasari dengan kepastian hukum, dan pengurusan sertifikat tanah harus secara lansung tanpa perantara" (Andi Nur Aeni 2019).

Berdasarkan hasil wawancara bahwa di Kantor Pertanahan Nasional Kota Kendari menyampaikan pesannya kepada masyarakat sudah sesuai dengan prosedur yang di terapkan di pertanahan berupa sertifikat tanah yang harus di dasari dengan kepastian hukum.

Lanjut pendapat yang serupa dari wawancara terhadap masyarakat bahwa media komunikasi yang digunakan oleh Kantor Pertanahan Nasional Kota Kendari menunjukkan sebagaian masyarakat belum mengetahui adanya aplikasi "SENTUH TANAHKU" dikarenakan belum adanya pembentukan sosialisasi sebelumnya tentang aplikasi SENTUH TANAHANKU” (Lisa, 2019).

Dari wawancara tersebut diketahui bahwa masih banyak masyarakat belum mengetahui tentang adanya media komunikasi berupa aplikasi SENTUH TANAHKU karna belum adanya sosialisasi yang dilakukan sebelumnya oleh pihak Kantor Pertanahan Nasional Kota Kendari.

Hasil wawancara beberapa informan dapat disimpulkan bahwa mediamedia yang digunakan atau pesan-pesan yang di informasikan oleh Kantor Pertanahan Nasional Kota Kendari kepada Masyarakat cukup efektif karna sudah mengunakan papan pengumuman, sosialisasi langsung kepada masyarakat, pelayanan langsung atau sosialisasi diluar kantor (one day servis di mall lippo plaza kendari), sosialisasi melalui pamflet, dan yang digunakan media tulisan seperti email (kot-kendari@bpn.yo.id), aplikasi “Sentu Tanahku”, facebook (BPN Kota Kendari) dan komunikasi dilakukan secara langsung dan bertatap muka. Tetapi masih ada sebagian masyarakat belum mengetahui bagaimana cara menggunakan secara efektif di karna kurangnya informasi. 


\section{c. Efek Komunikasi}

Efek komunikasi adalah pesan yang disebabkan oleh komunikator melalui media timbul pada komunikan sebab sasaran komunikasi mengenai efek komunikasi ini telah disinggung di muka diklarifikasikan sebagai efek kognitif (cognitive effect), efek efktif (effective effect) atau efek konatif yang sering disebut efek behavioral (behavioral effect) berhubungan dengan pikiran atau penalaran sehingga khalayak yang semula tidak tahu yang tadinya tidak mengerti, dan yang tadinya binggung menjadi merasa jelas.

Belajar dari media massa memang tidak bergantung hanya ada unsur stimuli dalam media massa saja. Kita memerlukan teori psikologi yang menjelaskan peristiwa belajar semacam ini. Teori psikolog yang dapat menjelaskan efek prososial adalah teori belajar sosial dari Bandura. Menurutnya, kita belajar bukan saja dari pengelaman langsung, tetapi dari peniruan atau peneladanan (modeling). Perilaku merupakan hasil faktor-faktor kognitif dan lingkungan. Artinya, kita mampu memiliki keterampila tertentu, bila terdapat jalinan positif antara stimuli yang kita amati dan karakteristik diri kita. Beranggapan bahwa efek hanya "perubahan perilaku manusia yang setelah diterap media pesan media massa" karena fokusnya pesan maka efek harusnya berkaitan dengan pesan yang disampaikan media massa. (Jalaluddin, 1994:18).

Penerapan Pelayanan Administrasi efek yang dihasilkan yaitu dapat memberikan kemudahan kepada masyarakt dan juga memberikan kemudahan dalam memberikan informasi seperti yang diungkapkan oleh Kepala Kantor Pertanahan nasional Kota Kendari menyatakan bahwa "Pelayanan yang kami lakukan sudah baik dan sesuai prosedur yang ada dikantor kami, kami juga sudah memberikan informasi-informasi melalui pamflet, papan pengumuman, sosialisasi diluar kantor (one day servis) atau situs web untunk melakukan pengurusan di kantor pertanahan" (Irwan Idrus, 2019).

Berdasarkan wawancara bahwa di Kantor Pertanahan Nasional Kota Kendari sudah banyak menginformasikan kepada masyarakat tentang Pelayanan Administrasi di pertanahan melalui beberapa media yang digunakan tetapi masih ada masyarakat yang belum memahami adanya media itu yang di gunakan oleh 
Kantor Pertanahan Nasional Kota Kendari itu sendiri untuk mendapatkan informasi yang jelas.

Lebih lanjut berdasarkan wawancara dengan KASUBSI Penataan Hak Tanah dan Pemberdayaan Masyarakat menyatakan bahwa semua informasiinformasi telah tersedia di pamflet maupun situs web. Jadi, masyarakat yang mengurus tinggal menyiapkan persyaratan-persyaratan yang diperlukan agar sistem kepengurusannya cepat selesai. (Sukma, 2019).

Berdasarkan hasil wawancara bahwa Kantor Pertanahan Nasional Kota Kendari sudah banyak mengunakan media seperti facebook, situs web, pamflet dan juga mengunakan papa pengumuman jadi informasi yang masyarakat butuhkan sudah semua tercantum pada media yang digunakan oleh Kantor Pertanahan Nasional Kota Kendari dan juga masyarakat tinggal menyediakan syarat-syarat yang di butuhkan oleh BPN agar sistem kepengurusannya cepat selesai dan tepat waktu.

Hal ini senada dengan hasil wawancara dengan pengguna layanan yang menyatakan bahwa "Sistem pelayanan di Badan Pertanahan Nasional kota Kendari sudah bagus dan baik yang penting sudah terpenuhi persyaratan-persyaratan yang di minta oleh Kantor Badan Pertanahan Nasional Kota Kendari” (Hasanuddin, 2019). Hal ini menunjukkan bahwa efek komunikasi di Kantor Pertanahan Nasional Kota Kendari sudah cukup bagus tetapi tergantung masyarakat bagaimana melengkapi berkasnya yang di minta oleh pertanahan supaya proses pengurusannya cepat terselesaikan dan tepat waktu yang sudah di janjikan oleh petugas.

Pendapat yang sama disampaikan oleh pengguna layanan yang menyatakan bahwa pelayanan yang dilakukan oleh Kantor Pertanahan Nasional Kota Kendari bagus dan pelayanan yang dilakukan cepat tergantung kelengkapan berkas atau persyaratan yang di minta oleh badan pertahanan nasional Kota Kendari (Isna, 2019). Berdasarkan hasil wawancara tersebut bahwa masyarakat menerima informasi tentang Pelayanan Administrasinya sudah jelas dan media yang digunakan oleh pihak Pertanahan sudah banyak, tetapi masih banyak masyarakat yang belum memahami sistem kepengurusannya di Pertanahan, jadi masyarakat 
lebih memilih mengunakan pelantara atau calo dibanding datang langsung di Kantor untuk pengurusan.

Hasil wawancara beberapa informan dapat disimpulkan bahwa informasi yang diberikan pada masyarakat sudah jelas karena sudah banyak media yang digunakan seperti papan pengumuman, sosialisasi langsung kepada masyarakat, pelayanan langsung atau sosialisasi di luar kantor (one day servis di mall lippo plaza Kendari), sosialisasi melalui pamflet, dan Media yang digunakan seperti email (kotkendari@bpn.yo.id), aplikasi “Sentu Tanahku”, facebook (BPN Kota Kendari), tetapi masih ada juga masyarakat yang belum memahami System kepengurusannya di Pertanahan, jadi masih ada masyarakat yang lebih memilih mengunakan pelantara atau calo dibanding datang langsung di kantor untuk pengurusan. Mengunakan pelantara atau calo pengurusan cepat tapi kenyataannya tidak karna mengunakan perantara atau calo banyak memakai biaya dan memerlukan waktu yang lama sedangkan pengurusan langsung di Kantor Pertanahan Nasional Kota Kendari tidak memakai biaya yang banyak dan tidak memerlukan waktu yang lama.

\section{Kesimpulan}

Berdasarkan dari hasil pembahasan di atas maka dapat ditarik kesimpulan dalam penelitian, bahwa keberhasilan komunikasi merupakan kunci keberhasilan dalam mencapai tujuan Kantor Pertanahan Nasional seperti komunikasi internal dan komunikasi eksternal. Komunikasi internal adalah hubungan antara atasan dan bawahan yang dalam komunikasinya terdapat berbagai mcam bentuk seperti rapat antara bawhan dan ataasan dalam menyususun sebuah rencana seperti, pendaftarana tanah, pembuatan akta tanah, dan sertifikat tanah, sehingga cukup efektif dalam melakukan pelayanan. Komunikasi eksternal juga sangatlah penting dalam instansi seperti adanya komunikasi antara staf atau pegawai instansi dengan masyarakat, serta menggunakan media online seperti internet, pamflet, dan spanduk, dalam memberikan informasi pelayanan. Dalam komunikasi eksternal, terdapat komunikator yang menyampaiakan informasi awal mengenai pelayanan kepada masyarakat, adapun komunikator yang dimaksud adalah pegawai yang dipilih oleh 
kepala kantor untuk menyampaiakan informasi. Efek komunikasi Merupakan pesan yang disebabkan oleh komunikator melalui media yang timbul pada komunikan. Sasaran komunikasi Penerapannya di Kantor Pertanahan Nasional Kota Kendari sudah banyak menginformasikan kepada masyarakat tentang pelayanan administrasi di pertanahan melalui beberapa media yang digunakan, sehingga pelayanan yang diterapkan cukup efektif.

\section{Referensi}

Aeni, Muhammad, 2001. Komunikasi Organisasi: PT. Bumi Aksara. Jakarta

Aeni, Muhammad. 2011. Ilmu Komunikasi Studi Pengantar. PT. Remaja Rosda Karya: Bandung.

Cangara, Hafied. 2007. Pengantar Ilmu Komunikasi. Jakarta: Raja Grafindo Persada.

Cambel, J. P. 1989. Riset Dalam Efektivitas Organisasi, Terjemahan Sahat Simamora. Jakarta : Erlangga.

Daryanto. 2010. Media Pembelajaran: Perannya Sangat Penting Dalam Mencapai Tujuan Pembelajaran. Yogyakarta : Gava Media.

Depdagri-LAN. 2007. Modul 1 Prinsip Dasar Komunikasi. Diklat Teknis Hubungan Masyarakat (PublicRelation). Jakarta: LAN RI.

Effendy, Onong Uchjana. 2011. Ilmu Komunikasi Teori dan Praktek. Bandung: PT. Remaja Rosdakarya.

Gomes, Faustina Cordoso. 2003. Manajemen Sumber Daya Manusia. Yogyakarta: Andi Offset.

Handayaningrat, Soewarno. 1994. Pengantar Ilmu Administrasi Dan Manajemen. Jakarta : CV. Haji Masagung

H.A.W. Widjaja. 2000. Ilmu Komunikasi Pengantar Studi. Rineka Cipta: Jakarta. Jamaluddin, Yanhar. 2016. Model Peningkatan Kualitas Pelayanan Publik. Jurnal TAPIs, Vol. 12, No.1 : 54-68.

Lubis, S.M. Hari \& Huseini, Martani (1987). Teori Organisasi : Suatu Pendekatan Makro. Jakarta : Pusat Antar Universitas Ilmu-Ilmu Sosial. 
Mulyana, Deddy. 2001. Ilmu Komunikasi: Suatu Pengantar. Bandung: Remaja Rosdakarya.

Nasution, Zulkarimen. 2004. Komunikasi Pembangunan Pengenalan Teori dan Penerapannya. PT. Raja Grafindo Persada: Jakarta.

Pasolong, Harbani, 2007. Teori Administrasi Publik. Bandung : Penerbit Alfabeta. Rakhmat, Jalaluddin. 2004. Metode Penelitian Komunikasi. PT. Remaja Rosda Karya : Bandung.

Ratminto \& Winarsih, Atik Septi. 2005. Manajemen Pelayanan. Yogyakarta : Pustaka Pelajar.

Sinambela, Lijan Poltak, dkk. 2006. Reformasi Pelayanan Publik. Jakarta: Bumi Aksara.

Somad, Rismi \& Donni Juni Priansha. 2014. Manajemen Komunikasi. Bandung: Alfabet.

Sedarmayanti, (2006). Sumber Daya Manusia Dan Produktivitas Kerja. Bandung Mandar Maju.

Tangkilisan, Hessel Nogi. 2005. Manajemen Publik. Jakarta: Grasindo. Wiryanto. 2004. Pengantar Ilmu Komunikasi. Jakarta: Grasindo.

\section{Wawancara}

Aeni, Andi Nur (2019). Kantor Pertahanan Kota Kendari, 15 Mei 2019

Hasanuddin (2019). Kendari, 23 Mei 2019

Idrus, Irwan (2019). Kantor Pertahanan Kota Kendari, 20 Mei 2019

Idrus, Muhtar, Kantor Pertahanan Kota Kendari, 28 Mei 2019

Jasip (2019). Kantor Pertahanan Kota Kendari, 20 Mei 2019

Lisa (2019). Kendari, 20 Mei 2019

Sandra (2019). Kantor Pertahanan Kota Kendari, 15 Mei 2019

Sukma (2019). Kantor Pertahanan Kota Kendari, 10 Mei 2019

Wirawan, Sultra (2019). Kantor Pertahanan Kota Kendari, 31 Mei 2019 